\title{
Correlates of blood pressure in 15 year olds in the West of Scotland
}

\author{
Sally Macintyre, Graham Watt, Patrick West, Russell Ecob
}

\begin{abstract}
Study objective-The aim was to examine social and physical correlates of blood pressure in 15 year olds.
\end{abstract}

Design-This was the first, baseline, sweep of a longitudinal survey of 15 year olds based on a two stage stratified clustered random sample.

Setting-The Central Clydeside Conurbation, in the West of Scotland. In 1981 this had a population of 1.7 million and a standardised mortality ratio (relative to Scotland as a whole) of 109.

Subjects-A random sample of households containing 15 year olds were approached by Strathclyde Regional Council; $70 \%$ agreed to have their names passed on to the MRC (15\% refused, $10 \%$ could not be contacted, and $5 \%$ had moved). Of these $1177,11 \%$ refused to participate, $3 \%$ were not contactable/had moved, and $4 \%$ did not provide full data. Complete blood pressure data are available for 95915 year olds (464 males and 495 females).

Measurements and main results-Blood pressure, pulse rate, height, weight, and room temperature were measured by nurses in the subjects' homes. Smoking, drinking, and frequency of vigorous exercise were self reported. Maternal height, birthweight, occupation of head of household, and housing tenure were reported by parents. After controlling for the other variables, systolic blood pressure was significantly associated with weight, pulse rate, and room temperature in males and with weight, pulse rate, housing tenure, smoking, and exercise in females. Diastolic blood pressure was associated with room temperature in males and with mother's height, pulse rate, and housing tenure in females. Controlling for current weight, birthweight was inversely related to systolic blood pressure in males and positively associated in females, though in neither case were these associations statistically significant.

Conclusions-In males, blood pressure was mainly related to anthropometric factors whereas in females it was additionally related to socioeconomic and behavioural variables. Although not reaching significance, the weight standardised relationship between birthweight and systolic blood pressure was consistent for males, but not females, with those reported by recent British studies of children and adults. The longitudinal design of this study will allow us to examine correlates of blood pressure in the same individuals as they reach social and physical maturity.

There has been considerable interest recently in Britain in early life antecedents of blood pressure. An inverse relationship between birthweight and blood pressure (controlling for current weight) has been reported among 5-7 year olds, ${ }^{1}$ and among 10 year olds and 36 year olds from the 1970 and the 1946 British birth cohorts. ${ }^{2}$ Significant differences have been reported between towns in the blood pressure of children aged 5-7 with the differences showing a similar pattern to those observed in middle aged men. ${ }^{3}$ These findings have been interpreted as indicating the importance of early, and particularly intrauterine, determinants of blood pressure levels in adults. ${ }^{4}$

There have been relatively few studies of blood pressure levels in adolescents, as compared to children or adults, in Britain. Studies of teenagers have, however, drawn attention to associations between blood pressure and social class, smoking, and exercise ${ }^{5-7}$; studies of adults have also indicated that current social class and alcohol consumption $^{8}$ may be associated with blood pressure.

This paper reports on blood pressure levels and their correlates in a cohort of 15 year olds in the West of Scotland who are being followed up as part of a broader study of social patterns in health. The focus of the study is not on blood pressure per se but blood pressure measurements were taken as part of a series of measures of development and functioning. This study can usefully contribute to discussions of blood pressure determinants, both because of the range of social and physical measures employed and because the cohort is being followed up at age 18 and periodically thereafter. Longitudinal observations of blood pressure levels during the period in which young people move away from influences in the parental home and create their own lifestyles may be useful in assessing the relative importance of earlier as compared with later environmental influences on blood pressure. This paper presents baseline cross sectional data on a cohort of adolescents before they leave home and school.

\section{Methods}

The objectives, design and methods of the "West of Scotland Twenty-07 Study: Health in the Community" have been described in detail elsewhere. ${ }^{910}$ It aims to explore the processes by which social patterns in health are produced, 
focusing in particular on variations in health by occupational class, gender, age, marital status, ethnicity, and area of residence. It is based on three cohorts, aged respectively 15, 35 and 55 years at the first baseline surveys in $1987 / 8$, which are being followed up at intervals using social survey techniques. It used a two stage stratified clustered random sample design based on 52 post code sectors in the Central Clyde Conurbation, a large and heterogeneous area around and including Glasgow City, with a population of 1.7 million and a standardised mortality ratio (relative to Scotland as a whole) of 109 in 1981 . $^{11}$

The sampling frame used was Strathclyde Regional Council's Voluntary Population Survey, an enhanced electoral register containing information on the age and sex composition of each household. ${ }^{12}$ Regional Council staff drew a random sample of 1682 households containing 15 year olds, whom they then approached for consent to pass their names on to the study team. In $15 \%$ cases the young people and/or parent refused consent; $10 \%$ could not be contacted after four attempts; and 5\% had moved between the time the sample was drawn and the attempted contact. Of the 1177 who agreed to be contacted about the study, $1009(86 \%)$ were interviewed in their own homes by a social interviewer and $996(82 \%)$ were visited by a nurse who took various physical measurements (see below). The sex ratio ( $48 \%$ boys) was slightly less than that of the population of 15 year olds in the Central Clydesdale Conurbation at the 1981 census $(51 \%)$. The proportion in non-manual households $(41 \%)$ was higher than the $33 \%$ shown in the 1981 census for households containing a child or children aged $0-15$ in the conurbation. This overrepresentation of non-manual households is attributable to response bias (middle class people usually participate more in surveys) and to changes in the social class distribution since 1981 . The fact that $46 \%$ of our sample lived in owner-occupied housing compared with $42 \%$ in the original sample drawn by the Strathclyde Regional Council indicates that the social class bias may be less than is indicated by comparisons with the 1981 census. Weighting schemes to compensate for response bias have been evaluated; these produce only negligible differences in the health or social measures, ${ }^{13}$ and therefore unweighted data are used in this analysis.

A wide range of measures of mental and physical health are being investigated in this study, including self reports (eg, of overall health status, the incidence of symptoms, and the prevalence of conditions), reports by parents, and observations or measurements made by nurses. The measures used in the present analysis are described below.

The nurses measured the subjects' pulse rate, blood pressure, height, weight, and hip and waist circumference, and recorded the temperature in the room in which the measurements were taken. Blood pressure was measured in the sitting position in the right arm after a 5 min rest, using a Hawkesley random zero sphygmomanometer. An adult size cuff (with inflatable bladder $35 \times 12 \mathrm{~cm}$ ) was used in all cases. ${ }^{14}$ Readings were taken to the nearest even number. Systolic and diastolic phase 5 were recorded. Two readings were taken and the mean values are reported here. Measurements were made by 35 nurses who were trained for the study using a film, a double headed stethoscope, and a series of measurement exercises on each other. Height was measured using Nivotoise stadiometers, and weight (to the nearest $0.5 \mathrm{~kg}$ ) by portable electronic scales calibrated at the local trading standards office. The body mass index used in this paper is the Quetelet index (weight in $\mathrm{kg} \div$ height $^{2}$ in metres). The full series of measurements was obtained on 959 subjects.

One or both parents were interviewed about family circumstances and the subject's early life. Information on birthweight was only sought from biological parents, and is available for 902 cases. The height of the natural mother was self reported, and is not known for cases in which a step parent was the interviewee. Behavioural data were self reported using standard questions. "Smokers" and "drinkers" are those who reported smoking or drinking "occasionally" or "regularly". Since almost all respondents reported doing sport at school, the measure of exercise used here is the frequency of vigorous exercise (causing the subject to get out of breath and sweat, and lasting more than 20 minutes at a time) taken outside school. The distribution varied markedly between males and females $(72 \%$ boys reported exercising outside school once or more a week compared with $37 \%$ girls). In this paper regular exercise is defined as that occurring outside school more than once a week for males (reported by $58 \%$ boys), and ever for females (reported by $50 \%$ girls), since this categorisation maximises comparability between the sexes. Social class is based on the 1980 Registrar General's Classification of Occupations, ${ }^{15}$ using the father's current or last occupation, or, if there was no father or if he had no occupation, the mother's current or last occupation. Housing tenure is used as an alternative measure of social class since it does not depend on employment status, nor on whether there is a father in the family.

The interviews were carried out over 12 months in 1987, the distribution across the year being roughly normal ( $56 \%$ taking place in May, June, July). There was a tendency for respondents in owner-occupied housing and from higher social class backgrounds to be interviewed earlier in the year (although this trend was only statistically significant for boys for housing tenure). From inspection of three frequency distributions across month of interview-number of interviews conducted, mean systolic blood pressure, and mean room temperature-months of interview were divided into three periods. These were summer (June and July: number of subjects $=364$ ); spring and autumn (April, May, August, September; $n=440$ ), and winter (January, February, March, October, November, December; $n=142$ ). The mean room temperatures recorded in these three seasons were: $\quad$ summer $=20.8^{\circ} \mathrm{C}$, spring and autumn $=20 \cdot 1^{\circ} \mathrm{C}$, and winter $=18 \cdot 7^{\circ} \mathrm{C}(\mathrm{F}=80 \cdot 6$, $\mathrm{p}=<0.0001$ ).

In order to maximise comparability with studies which present data separately for males and females, and which suggest that there are sex differences in the relationship between various 
factors and blood pressure, (eg 571617 ) we conducted our analysis separately for males and females. One way analysis of variance was used for the univariate analysis of the categorical independent variables. Simple regression and multiple regression was used to analyse the continuous variables and the categorical variables (the latter being entered as dummy binary variables). The significance of sex differences in relationships with blood pressure was tested by examining two way interactions with sex in an analysis of variance (ANOVA) combining both sexes and with the continuous variables grouped into tertiles.

Results

Mean systolic blood pressure was $114 \cdot 4$ (SD 12.1) $\mathrm{mm} \mathrm{Hg}$ in males and $108.8(10.9) \mathrm{mm} \mathrm{Hg}$ in females. Mean diastolic blood pressure was 65.9 (9.9) in males and 66.4 (9.7) in females.

Tables I and II present data from the univariate analysis and show, respectively, mean systolic and mean diastolic blood pressures by the categorical social and behavioural variables. Females in owner-occupied housing have lower blood pressure than others $(F=5.09, p<0.05$ for systolic; $F=4.76, p<0.05$ for diastolic). Females

Table I Systolic blood pressure ( $\mathrm{mm} \mathrm{Hg}$ ): mean values withingroups, males and females.

\begin{tabular}{|c|c|c|c|c|c|c|}
\hline & \multicolumn{3}{|l|}{ Males } & \multicolumn{3}{|l|}{ Females } \\
\hline & Mean & $S D$ & $n$ & Mean & $S D$ & $n$ \\
\hline All & $114 \cdot 4$ & $12 \cdot 1$ & 464 & $108 \cdot 8$ & 10.9 & 495 \\
\hline $\begin{array}{l}\text { Non-manual social class } \\
\text { Manual social class }\end{array}$ & $\left.\begin{array}{l}115 \cdot 8 \\
113 \cdot 4\end{array}\right] \star$ & $\begin{array}{l}12 \cdot 7 \\
11 \cdot 5\end{array}$ & $\begin{array}{l}199 \\
261\end{array}$ & $\begin{array}{l}108 \cdot 8 \\
109 \cdot 0\end{array}$ & $\begin{array}{l}10 \cdot 2 \\
11 \cdot 6\end{array}$ & $\begin{array}{l}200 \\
287\end{array}$ \\
\hline $\begin{array}{l}\text { Owner-occupiers } \\
\text { Other }\end{array}$ & $\begin{array}{l}115 \cdot 3 \\
113 \cdot 6\end{array}$ & $\begin{array}{l}11 \cdot 9 \\
12 \cdot 1\end{array}$ & $\begin{array}{l}227 \\
234\end{array}$ & $\left.\begin{array}{l}107 \cdot 7 \\
109 \cdot 9\end{array}\right] \star$ & $\begin{array}{l}10 \cdot 3 \\
11 \cdot 5\end{array}$ & $\begin{array}{l}222 \\
264\end{array}$ \\
\hline $\begin{array}{l}\text { Non-smoker } \\
\text { Smoker }\end{array}$ & $\begin{array}{l}114 \cdot 5 \\
113 \cdot 3\end{array}$ & $\begin{array}{l}12 \cdot 3 \\
10 \cdot 9\end{array}$ & $\begin{array}{r}288 \\
76\end{array}$ & $\left.\begin{array}{l}109 \cdot 3 \\
106 \cdot 7\end{array}\right] \star$ & $\begin{array}{l}11 \cdot 0 \\
10 \cdot 7\end{array}$ & $\begin{array}{r}406 \\
89\end{array}$ \\
\hline $\begin{array}{l}\text { Non-drinker } \\
\text { Drinker }\end{array}$ & $\begin{array}{l}113 \cdot 9 \\
115 \cdot 1\end{array}$ & $\begin{array}{l}11 \cdot 8 \\
12 \cdot 5\end{array}$ & $\begin{array}{l}315 \\
149\end{array}$ & $\begin{array}{l}108 \cdot 9 \\
108 \cdot 4\end{array}$ & $\begin{array}{l}10 \cdot 9 \\
11 \cdot 0\end{array}$ & $\begin{array}{l}387 \\
108\end{array}$ \\
\hline $\begin{array}{l}\text { Frequent exercise } \\
\text { Less frequent exercise }\end{array}$ & $\begin{array}{l}114 \cdot 7 \\
113.9\end{array}$ & $\begin{array}{l}12 \cdot 0 \\
12 \cdot 2\end{array}$ & $\begin{array}{l}271 \\
192\end{array}$ & $\left.\begin{array}{l}110 \cdot 1 \\
107 \cdot 6\end{array}\right]$ * & $\begin{array}{l}10 \cdot 2 \\
11 \cdot 7\end{array}$ & $\begin{array}{l}249 \\
242\end{array}$ \\
\hline $\begin{array}{l}\text { Summer } \\
\text { Spring/autumn } \\
\text { Winter }\end{array}$ & $\begin{array}{l}115.3 \\
113.9 \\
113.1\end{array}$ & $\begin{array}{l}12.9 \\
11 \cdot 1 \\
12 \cdot 7\end{array}$ & $\begin{array}{r}171 \\
226 \\
62\end{array}$ & $\begin{array}{l}108 \cdot 9 \\
108 \cdot 0 \\
109 \cdot 4\end{array}$ & $\begin{array}{r}11 \cdot 6 \\
9.8 \\
12.0\end{array}$ & $\begin{array}{r}193 \\
214 \\
80\end{array}$ \\
\hline
\end{tabular}

${ }^{\star} \mathrm{p}<0.05$

Table II Diastolic blood pressure ( $\mathrm{mm} \mathrm{Hg}$ ): mean values within groups, males and females.

\begin{tabular}{|c|c|c|c|c|c|c|}
\hline & \multicolumn{3}{|l|}{ Males } & \multicolumn{3}{|l|}{ Females } \\
\hline & Mean & $S D$ & $n$ & Mean & $S D$ & $n$ \\
\hline All & $65 \cdot 9$ & $9 \cdot 9$ & 464 & $66 \cdot 4$ & $9 \cdot 7$ & 495 \\
\hline $\begin{array}{l}\text { Non-manual social class } \\
\text { Manual social class }\end{array}$ & $\begin{array}{l}66 \cdot 9 \\
65 \cdot 2\end{array}$ & $\begin{array}{r}9 \cdot 6 \\
10 \cdot 1\end{array}$ & $\begin{array}{l}199 \\
261\end{array}$ & $\begin{array}{l}67 \cdot 0 \\
66 \cdot 2\end{array}$ & $\begin{array}{r}9 \cdot 4 \\
10 \cdot 0\end{array}$ & $\begin{array}{l}200 \\
287\end{array}$ \\
\hline $\begin{array}{l}\text { Owner-occupiers } \\
\text { Other }\end{array}$ & $\begin{array}{l}66 \cdot 2 \\
65 \cdot 7\end{array}$ & $\begin{array}{l}9 \cdot 8 \\
9 \cdot 9\end{array}$ & $\begin{array}{l}227 \\
234\end{array}$ & $\left.\begin{array}{l}65 \cdot 5 \\
67 \cdot 4\end{array}\right] \star$ & $\begin{array}{l}9 \cdot 5 \\
9 \cdot 9\end{array}$ & $\begin{array}{l}224 \\
264\end{array}$ \\
\hline $\begin{array}{l}\text { Non-smoker } \\
\text { Smoker }\end{array}$ & $\begin{array}{l}65 \cdot 9 \\
65 \cdot 3\end{array}$ & $\begin{array}{r}10 \cdot 1 \\
8 \cdot 7\end{array}$ & $\begin{array}{r}388 \\
76\end{array}$ & $\left.\begin{array}{l}66 \cdot 9 \\
64.2\end{array}\right] \star$ & $\begin{array}{l}9 \cdot 7 \\
9 \cdot 6\end{array}$ & $\begin{array}{r}406 \\
89\end{array}$ \\
\hline $\begin{array}{l}\text { Non-drinker } \\
\text { Drinker }\end{array}$ & $\begin{array}{l}65 \cdot 9 \\
65 \cdot 6\end{array}$ & $\begin{array}{r}9 \cdot 8 \\
10 \cdot 7\end{array}$ & $\begin{array}{l}315 \\
149\end{array}$ & $\begin{array}{l}66 \cdot 5 \\
66 \cdot 1\end{array}$ & $\begin{array}{l}9 \cdot 8 \\
9 \cdot 7\end{array}$ & $\begin{array}{l}387 \\
108\end{array}$ \\
\hline $\begin{array}{l}\text { Frequent exercise } \\
\text { Less frequent exercise }\end{array}$ & $\begin{array}{l}65 \cdot 3 \\
66 \cdot 8\end{array}$ & $\begin{array}{r}10 \cdot 0 \\
9 \cdot 5\end{array}$ & $\begin{array}{l}271 \\
192\end{array}$ & $\begin{array}{l}66 \cdot 7 \\
66 \cdot 3\end{array}$ & $\begin{array}{l}9 \cdot 7 \\
9 \cdot 8\end{array}$ & $\begin{array}{l}249 \\
242\end{array}$ \\
\hline $\begin{array}{l}\text { Summer } \\
\text { Spring/autumn } \\
\text { Winter }\end{array}$ & $\begin{array}{l}66 \cdot 0 \\
65 \cdot 6 \\
65 \cdot 8\end{array}$ & $\begin{array}{r}9.9 \\
9 \cdot 5 \\
10 \cdot 8\end{array}$ & $\begin{array}{r}171 \\
226 \\
62\end{array}$ & $\begin{array}{l}66 \cdot 8 \\
66 \cdot 1 \\
65 \cdot 7\end{array}$ & $\begin{array}{r}9 \cdot 8 \\
9 \cdot 3 \\
10 \cdot 7\end{array}$ & $\begin{array}{r}193 \\
214 \\
80\end{array}$ \\
\hline
\end{tabular}

$\star_{\mathrm{p}}<0.05$ who smoke have lower blood pressures than those who do not $(\mathrm{F}=3.89, \mathrm{p}<0.05$ for systolic; $\mathrm{F}=5.79, \mathrm{p}<0.05$ for diastolic). However, mean pulse rate was more strongly associated with smoking among males ( 73.6 beats $/ \mathrm{min}$ for smokers $v 69.9$ for non-smokers; $\mathrm{p}<0.001$ ) than among females ( $75.6 v 73.8$; NS). Both males and females who reported taking more frequent exercise outside school had higher systolic blood pressure, though the difference was only significant for females $(p<0.05)$. There were no differences in diastolic pressures by exercise category. In males resting pulse rate was lower in those exercising more frequently $(69.5$ beats $/ \mathrm{min}$ $v 71.9 ; \mathrm{p}<0.05)$; the same was true for females though the difference was not significant $(73.7 v$ 74.6 ; NS). In males systolic blood pressure was higher in summer than in spring/autumn or winter, but not significantly so. There are no other seasonal trends discernible.

The simple regression coefficients for systolic and diastolic blood pressure by the continuous variables are presented in tables III and IV. (These tables only include subjects- 413 males and 425 females - for whom data were available for all the variables; therefore the totals differ from those given in tables I and II.) Systolic blood pressure is statistically significantly correlated with weight, height, pulse rate, and body mass index in both males and females, and with room temperature in males only and with mother's height in females only. Diastolic blood pressure is significantly correlated with weight and body mass index in both sexes and with room temperature and height for males. The correlations with both systolic and diastolic pressure are mostly higher for males than for females.

Room temperature was higher in non-owner occupied households than owner occupied housholds (for males $21.5^{\circ} \mathrm{C} v 20.0^{\circ} \mathrm{C}, \mathrm{F}=9.08$, $\mathrm{p}<0.001$; for females $20.7^{\circ} \mathrm{C} v 20.0^{\circ} \mathrm{C}, \mathrm{F}=4.31$, $\mathrm{p}<0.05)$. For females, but not males, room temperatures were higher in manual than in non-manual households $\left(20.7^{\circ} \mathrm{C} v 19.9^{\circ} \mathrm{C}\right.$, $\mathrm{F}=5.37, \mathrm{p}<0.05$ ).

Other studies have found an inverse relationship between birth weight and mean systolic blood pressure, but only when standardised for current weight. ${ }^{12}$ In these 15 year olds the weight standardised regression coefficients were $-1.26 \mathrm{~mm} / \mathrm{kg}\left(95^{\circ}{ }_{0}\right.$ confidence interval $=-3.01$ to 0.47 ) for boys, and 0.52 $\mathrm{mm} / \mathrm{kg}$ (95\% confidence interval $=-1.28$ to 2.34 ) for girls. These regression coefficients are not significantly different from zero.

Though not statistically significant, for males these findings are in the same direction as those of other studies, their weight standardised regression coefficients $\left(-1.58\right.$ for $5-7$ year olds, ${ }^{1}$ -0.38 for 10 year olds, ${ }^{2}$ and -2.57 for 35 year olds $^{2}$ ) lying within the confidence intervals in our study. However, for females our results are inconsistent with those of others since we find a positive rather than inverse relationship between birthweight and systolic blood pressure, and our $95 \%$ confidence intervals do not include the coefficients reported by others $(-2.03$ for $5-7$ year olds, ${ }^{1}-1.32$ for 10 year olds, ${ }^{2}$ and -1.83 for 35 year olds ${ }^{2}$ ). 
The results of a multiple regression analysis of systolic and diastolic blood pressure, entering all the variables used in the preceding analyses (except for body mass index, since weight and height are components of the index and are thus already included in the multiple regression), are also shown in tables III and IV.

After controlling simultaneously for all the other variables, systolic blood pressure remains significantly associated with weight and pulse rate in both sexes, with weight having a greater effect on male pressures than on females pressures. Room temperature remains significantly associated with systolic pressure in males, and housing tenure, smoking, and exercise remains associated with systolic pressure in females. The effect of height disappears in both sexes.

In males, room temperature is the only variable that predicts diastolic pressure after controlling for all the other variables; in females, mother's height, pulse rate, and housing tenure remain significantly associated. Less of the variance in diastolic pressure $5.6 \%$ for females and $6.7 \%$ for males) was explained than of that in systolic pressure $(15.1 \%$ and $19.4 \%$ respectively).

The differences between the sexes in association with systolic blood pressure were significant for weight $(\mathrm{p}<0 \cdot 1)$, housing tenure $(\mathrm{p}<0.05)$, and smoking $(\mathrm{p}<0.05)$. There were no significant interactions with sex in relation to diastolic blood pressure.

\section{Discussion}

Mean values for both systolic and diastolic blood pressure in this study were lower than those reported for similar age groups by most of the US studies, ${ }^{1819}$ and than those produced by pooling results from 79 studies from all over the world. ${ }^{20}$ They are however similar to those reported for Greece and Italy. ${ }^{18}$ The systolic values are also lower than the 122 for boys and 113 for girls reported among 15 year olds in a Nottingham general practice. ${ }^{7}$ These lower levels may be due to the smaller stature of this Scottish sample (mean height was $171.6 \mathrm{~cm}$ for boys and $161.7 \mathrm{~cm}$ for girls). Unfortunately many studies do not report height data.

In this sample, associations between the factors examined and blood pressure differed between males and females. As has been reported in other studies, ${ }^{7}$ in males the strongest associations were with anthropometric measures such as weight and height, and more of the variance in blood pressure (particularly systolic blood pressure) was explained by the available data than it was for females. In females associations with blood pressure were additionally shown for mother's height, housing tenure, smoking, and exercise outside school. Females who took more exercise outside school, and those who did not smoke, had significantly higher systolic pressures. Similar findings on lowered systolic pressures among female smokers in this age group have previously been reported. ${ }^{16}$ The sex difference in the association with smoking cannot be explained by higher consumption among the girls (female smokers reported lower mean cigarette consumption than male smokers: 32.8 per week compared to 40.3 per week respectively). It might,
Table III Systolic blood pressure: simple regression coefficients, and regression coefficients controlling for the other variables

Table IV Diastolic blood pressure: simple regression coefficients, and regression coefficients controlling for the other variables

\begin{tabular}{|c|c|c|c|c|c|c|c|c|}
\hline & \multicolumn{4}{|c|}{ Males $(n=413)$} & \multicolumn{4}{|c|}{ Females $(n=425)$} \\
\hline & $\begin{array}{l}\text { Simple } \\
\text { regression } \\
\text { coefficient }\end{array}$ & $S E M$ & $\begin{array}{l}\text { Multiple } \\
\text { regression } \\
\text { coefficient }\end{array}$ & $S E M$ & $\begin{array}{l}\text { Simple } \\
\text { regression } \\
\text { coefficient }\end{array}$ & $S E M$ & $\begin{array}{l}\text { Multiple } \\
\text { regression } \\
\text { coefficient }\end{array}$ & $S E M$ \\
\hline $\begin{array}{l}\text { Body mass index }\left(\mathrm{kg} / \mathrm{m}^{2}\right) \\
\text { Birthweight }(\mathrm{kg}) \\
\text { Weight }(\mathrm{kg}) \\
\text { Height }(\mathrm{cm}) \\
\text { Mother's height }(\mathrm{cm}) \\
\text { Room temperature }\left({ }^{\circ} \mathrm{C}\right) \\
\text { Pulse rates (beats } / \mathrm{min}) \\
\text { Summer } \\
\text { Winter } \\
\text { Social class } \\
\text { Housing tenure } \\
\text { Smoking } \\
\text { Drinking } \\
\text { Exercise }\end{array}$ & $\begin{array}{c}1.50 \ddagger \\
0.44 \\
0.43 \dagger \\
0.26 \ddagger \\
-0.00 \\
-0.49^{\star} \\
0.12^{\star} \\
-1.77 \\
-0.82 \\
-2.41^{\star} \\
-1.81 \\
-1.95 \\
-1.51 \\
-1.37\end{array}$ & $\begin{array}{l}0.19 \\
0.97 \\
0.05 \\
0.08 \\
0 \cdot 09 \\
0 \cdot 25 \\
0.06 \\
1 \cdot 22 \\
1.19 \\
1.28 \\
1.18 \\
1.65 \\
1.28 \\
1.37\end{array}$ & $\begin{array}{l}-\overline{-} \\
-0.45 \\
0.50 \ddagger \\
-0.09 \\
-0.15 \\
-0.54 \\
0.17 \dagger \\
-1.86 \\
-1.34 \\
-1.24 \\
0.64 \\
-2.13 \\
0.88 \\
-1.57\end{array}$ & $\begin{array}{l}- \\
0.85 \\
0.06 \\
0 \cdot 09 \\
0 \cdot 08 \\
0 \cdot 22 \\
0.05 \\
1.09 \\
1.55 \\
1.13 \\
1.17 \\
1.42 \\
1.13 \\
1.15\end{array}$ & $\begin{array}{c}0.72 \ddagger \\
1 \cdot 61^{\star} \\
0 \cdot 28 \ddagger \\
0 \cdot 16^{\star} \\
0.19^{\star} \\
-0.25^{\star} \\
0.25 \ddagger \\
-0.60 \\
1.30 \\
0.58 \\
2 \cdot 25^{\star} \\
-2.68^{\star} \\
-0.98 \\
-2.86 \dagger\end{array}$ & $\begin{array}{l}0 \cdot 17 \\
0.94 \\
0 \cdot 06 \\
0 \cdot 09 \\
0 \cdot 09 \\
0 \cdot 22 \\
0 \cdot 06 \\
1 \cdot 08 \\
1.43 \\
1 \cdot 07 \\
1 \cdot 05 \\
1.44 \\
1.29 \\
1.05\end{array}$ & $\begin{array}{l}- \\
0.63 \\
0.26 \ddagger \\
-0.07 \\
0.18 \\
-0.28 \\
0.27 \ddagger \\
-0.92 \\
1.49 \\
-0.22 \\
3.22 \dagger \\
-3.43^{\star} \\
-0.72 \\
-2.42^{\star}\end{array}$ & $\begin{array}{l}- \\
0.95 \\
0 \cdot 06 \\
0 \cdot 11 \\
0 \cdot 09 \\
0 \cdot 22 \\
0 \cdot 06 \\
1 \cdot 13 \\
1.48 \\
1 \cdot 14 \\
1 \cdot 14 \\
1.43 \\
1 \cdot 25 \\
1.01\end{array}$ \\
\hline
\end{tabular}

Categorical variables: non-smoker $=0$, smoker $=1$; frequent exercise $=0$, less frequent $=1$; non-manual class $=0$, manual $=1$; owner occupier $=0$, other $=1 ;$ non-drinker $=0$, drinker $=1 ;$ summer $=0$, spring $/$ autumn $/$ winter $=1 ;$ winter $=1$, spring $/$ autumn $/$ summer $=0$ $\star \mathrm{p}<0.05 ; \dagger \mathrm{p}<0.01 ; \neq \mathrm{p}<0.00$

\begin{tabular}{|c|c|c|c|c|c|c|c|c|}
\hline & \multicolumn{4}{|c|}{ Males $(n=413)$} & \multicolumn{4}{|c|}{ Females $(n=425)$} \\
\hline & $\begin{array}{l}\text { Simple } \\
\text { regression } \\
\text { coefficient }\end{array}$ & $S E M$ & $\begin{array}{l}\text { Multiple } \\
\text { regression } \\
\text { coefficient }\end{array}$ & $S E M$ & $\begin{array}{l}\text { Simple } \\
\text { regression } \\
\text { coefficient }\end{array}$ & $S E M$ & $\begin{array}{l}\text { Multiple } \\
\text { regression } \\
\text { coefficient }\end{array}$ & $S E M$ \\
\hline Body mass index $\left(\mathrm{kg} / \mathrm{m}^{2}\right)$ & $0 \cdot 42^{\star}$ & $0 \cdot 17$ & - & - & $0 \cdot 32^{\star}$ & $0 \cdot 15$ & - & - \\
\hline Birthweight $(\mathbf{k g})$ & $1 \cdot 19$ & 0.81 & 0.64 & 0.85 & 0.75 & 0.83 & 0.69 & 0.87 \\
\hline Weight (kg) & $0.14 \dagger$ & 0.05 & 0.11 & 0.06 & $0 \cdot 10^{\star}$ & 0.05 & $0 \cdot 11$ & 0.06 \\
\hline Height $(\mathrm{cm})$ & $0 \cdot 14^{\star}$ & 0.07 & 0.06 & 0.09 & 0.01 & 0.08 & -0.17 & $0 \cdot 10$ \\
\hline Mother's height $(\mathrm{cm})$ & 0.08 & 0.08 & 0.01 & 0.08 & $0 \cdot 13^{\star}$ & 0.08 & $0 \cdot 19^{\star}$ & 0.09 \\
\hline Room temperature $\left({ }^{\circ} \mathrm{C}\right)$ & $-0.69 \ddagger$ & $0 \cdot 20$ & $-0.73 \ddagger$ & 0.22 & $-0 \cdot 11$ & 0.20 & $-0 \cdot 18$ & 0.21 \\
\hline Pulse rates (beats/min) & $0.08^{\star}$ & 0.05 & 0.10 & 0.05 & 0.09 & 0.05 & $0.11^{\star}$ & 0.05 \\
\hline Summer & $0 \cdot 10$ & 1.02 & $-1 \cdot 12$ & 1.09 & -0.49 & 0.95 & -0.25 & 1.04 \\
\hline Winter & 0.88 & 1.45 & 0.46 & 1.55 & -0.34 & 1.25 & -0.50 & $1 \cdot 37$ \\
\hline Social class & -1.37 & 0.99 & -0.73 & $1 \cdot 13$ & $-0 \cdot 70$ & 0.94 & -1.68 & 1.05 \\
\hline Housing tenure & -0.62 & 0.99 & $1 \cdot 11$ & $1 \cdot 17$ & $1.95^{\star}$ & 0.93 & $3 \cdot 15 t$ & 1.05 \\
\hline Smoking & -0.58 & 1.37 & -0.56 & 1.42 & $-1 \cdot 46$ & 1.26 & $-2 \cdot 00$ & $1 \cdot 32$ \\
\hline Drinking & -0.22 & 1.07 & -0.32 & 1.13 & -0.02 & 0.92 & 0.28 & $1 \cdot 16$ \\
\hline Exercise & 1.60 & $1 \cdot 13$ & $1 \cdot 38$ & 1.15 & -0.79 & 0.93 & -0.56 & 0.93 \\
\hline
\end{tabular}

Categorical variables: non-smoker $=0$, smoker $=1 ;$ frequent exercise $=0$, less frequent $=1 ;$ non-manual class $=0$, manual $=1$; owner

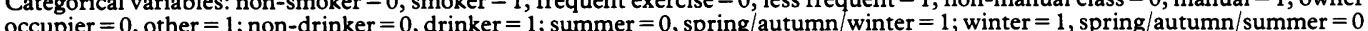
${ }_{\star} \mathrm{c}<0.05 ; \mathrm{tp}<0.01 ; \neq \mathrm{p}<0.001$
0.001 
however, be explained by females having started to smoke earlier, given their relatively greater social maturity at this age, but unfortunately we do not have data on the age our subjects started smoking, although we are seeking this information at our current contact with this cohort. Other studies of the effects of sports activity have either shown lower systolic pressures among exercise takers ${ }^{7}$ or no relationship with exercise. ${ }^{1721}$

The association with housing tenure cannot be explained by variations in room temperature. Housing tenure is, in Scotland at least, a good proxy measure for socioeconomic circumstances and is often found to be correlated with health indices as closely or more closely than occupationally based measures of social class. ${ }^{22} \mathrm{~A}$ recent paper on 15 year olds in Finland has shown that systolic blood pressures among girls, but not boys, were significantly associated with family socieconomic circumstances such as years of education of father and gross family income. ${ }^{17}$ Our data therefore seem to confirm findings from elswhere that blood pressure in females may be more highly correlated with socioeconomic and behavioural factors than blood pressure in males. From these cross sectional data it is not clear whether these associations in females are due to relatively recent (or current) social or material environmental circumstances, or to perinatal or lifetime exposure to these circumstances.

In contrast to recent studies of children and adults $^{12}$ no significant association was found between systolic pressure and birthweight even after controlling for current weight, although for males we found a non-significant inverse association that is consistent with the findings of these studies. For females our findings are not consistent with those of other studies. Our birthweight data were retrospectively reported, but so were the data used in other studies, ${ }^{1}$ and it has been shown that maternal reports of birthweight are reasonably reliable. ${ }^{2324}$ We therefore do not think it likely that our findings are due to unreliable birthweight data. They may, however, be due to the effects of puberty and differential rates of maturation. Because we are following up this cohort at age 18 and beyond, it will be possible to see whether significant associations with birthweight emerge as the cohort reaches adulthood, ie, whether they have been obscured by pubertal changes. Equally, it will be possible to study the relative importance of behavioural factors (smoking, alcohol consumption, and exercise patterns), socioeconomic factors, and early life experiences on blood pressure at different stages of the life cycle.

We would like to thank the nurse-interviewers and subjects who took part in this study, which is financed by the Medical Research Council. We are also grateful to
Gill Green and Lindsay MacAulay for assistance with data preparation, Jean Money and Edna MacIntyre for typing various drafts of this paper, and Tony Lever, Kate Hunt and Sally Wyke for comments on an earlier draft.

1 Whincup PH, Cook DG, Shaper AG. Early influences on blood pressure; a study of children aged 5-7 years. $B M \mathcal{F}$ 1989; 299: 587-91.

2 Barker DJP, Osmond C, Golding J, Kuh D, Wadsworth MEJ. Growth in utero, blood pressure in childhood and adult life, and mortality from cardiovascular disease. $B M F$ 1989; 298: 564-7.

3 Whincup PH, Cook DG, Shaper AG, Macfarlane DJ, Walker M. Blood pressure in British children: associations with adult blood pressure and cardiovascular mortality. Lancet 1988; ii: 890-3.

4 Barker DJP, Osmond C, Law CM. The intrauterine and early postnatal origins of cardiovascular disease and chronic bronchitis. $f$ Epidemiol Community Health 1989; 43: bronchitis.

5 Szklo $M$. Epidemiologic patterns of blood pressure in children. Epidemiol Rev 1979; 1: 143-69.

6 Hofman A, Valkenberg HA. Distribution and determinants of blood pressure in free-living children. In: Kesteloot $\mathrm{H}$, Joossens JV, eds. Epidemiology of arterial blood pressure. The Hague: Martinus Nijhoff, 1980: 99-117.

7 Orchard JJ, Hedley AJ, Mitchell JRA. The distribution and association of blood pressure in an adolescent population. $f$ Epidemiol Community Health 1982; 36: 35-42.

8 Shaper AG, Pocock SJ, Walker M, Cohen NM, Wale CJ. Thomson AG. British Regional Heart Study: cardiovascular risk factors in middle aged men in 24 towns. BMF 1981; 283: 179-86.

9 Ecob R. West of Scotland Twenty-07 study: the sampling scheme, frame and procedure. MRC Medical Sociology Unit Working Paper No 6, 1987. (Available from first author.)

10 Macintyre S, Annandale E, Ecob R, et al. The West of Scotland Twenty-07 Study: Health in the Community. In: Martin C, MacQueen DJ, eds. Readings for a new public health. Edinburgh: Edinburgh University Press, 1989.

11 MacIver S. West of Scotland Twenty-07 Study: Sociodemographic mortality profiles of the study areas. MRC Medical Sociology Unit working paper No 10,1988. (Available from first author.)

12 Black R. Instead of the 1986 Census: the potential contribution of enhanced registers. $\mathcal{F} R$ Stat $S o c$ 1985; 148 : 287-316.

13 Ecob R. Evaluation of weighting schemes for the regional samples of the Twenty-07 Study cohorts. MRC Medical Sociology Unit Working Paper No 20, 1990. (Available from first author.)

14 O'Brien E, Fitzgerald D, O'Malley K. Blood pressure measurement: current practice and future trends. $B M F$ 1985; 290: 729-34.

15 Office of Population Censuses and Surveys. Registrar General's Classification of Occupations 1980. London: HMSO, 1980.

16 Cornoni-Huntley J, Harlan WR, Leaverton PE. Blood pressure in adolescence: The United States Health Examination Survey. Hypertension 1979; 1: 566-71.

17 Marti B, Vartiainen E. Relation between leisure time exercise and cardiovascular risk factors among 15-year-olds in eastern Finland. $\mathcal{f}$ Epidemiol Community Health 1989; 43: 228-33.

18 National Heart, Lung and Blood Institute's Task Force on Blood Pressure in Children. Report of the Task Force on Blood Pressure in Children. Pediatrics 1977; 59: 797-820.

19 Bersenson GS, Cresanta JL, Webber LS. High blood pressure in the young. Am Rev Med 1984; 35: 535-60.

20 Brotons $C$, Singh $P$, Nishio T, Labarthe DR. Blood pressure by age in childhood and adolescence: a review of 129 surveys worldwide. Int f Epidemiol 1989; 18: 824-9.

21 Fagard R, M'Buyamba JR, Staesson J, Vanhees L, Amery A. Physical activity and blood pressure. In: Bulpitt CJ, ed. Handbook of Hypertension. Vol 6. Epidemiology of Hypertension. Amsterdam: Elsevier, 1985: ch 7.

22 Macintyre S, West P. Lack of class variation in health in adolescence: an artefact or an occupational measure of social class? Soc Sci Med 1991; 32: 395-402.

23 Seidman DS, Slater PE, Ever-Hadani P, Gale R. Accuracy of mothers' recall of birthweight and gestational age. $\mathrm{Br} \mathcal{F}$ Obstet Gynaecol 1987; 94: 731-5.

24 Eaton-Evans J, Dugdale AE. Recall by mothers of the birthweight and feeding of their children. Hum Nutr Appl Nutr 1986; 40A: 171-5. 